\title{
Bolesnici liječeni u Jedinici intenzivnog liječenja Klinike za infektivne bolesti „Dr. Fran Mihaljević” u Zagrebu zbog bolesti COVID-19
}

\author{
Critically ill patients with COVID-19 treated in the Intensive Care Unit at the University Hospital \\ for Infectious Diseases „Dr. Fran Mihaljević" in Zagreb \\ Anita Atelj ${ }^{1}$, Vladimir Krajinović ${ }^{1}$, Marija Santini ${ }^{1,2}$, Neven Papićc ${ }^{1,2}$, Martina Vargović ${ }^{1}$, Viktor Kotarski ${ }^{1}$, Branimir Gjurašin ${ }^{1}$, Juraj Krznarić1, Marko Kutleša ${ }^{1,2}$ \\ ${ }^{1}$ Klinika za infektivne bolesti „Dr. Fran Mihaljević," Zagreb \\ ${ }^{2}$ Medicinski fakultet, Sveučilište u Zagrebu, Hrvatska
}

Ključne riječi:

COVID-19

kritično oboljeli

intenzivno liječenje

Keywords:

COVID-19

critically ill

extensive treatment

Primljeno: 15-6-2020

Received: 15-6-2020

Prihvaćeno: 2-7-2020

Accepted: 2-7-2020

$\square$ Adresa za dopisivanje:

Klinika za infektivne bolesti „Dr. Fran Mihaljevic", Zagreb

Anita Atelj, dr. med.

e-mail: atelj.anita@gmail.com

\section{Sažetak}

Cilj: Opisati karakteristike bolesnika, tijek bolesti, terapiju te ishod i komplikacije kod kritično oboljelih s COVID-19 liječenih u jedinici intenzivnog liječenja (JIL) Klinike za infektivne bolesti „Dr. Fran Mihaljević” (KZIB) u Zagrebu.

Materijali i metode: Opservaciijka retrospektivna studija 38 odraslih bolesnika liječenih u JIL KZIB s dokazanim COVID-19 u razdoblju od 11. ožujka do 6. lipnja 2020. godine.

Rezultati: Od ukupno 167 bolesnika s COVID-19 liječenih u KZIB, u JIL-u je liječeno 38 bolesnika (22,8\%). Medijan dobi IlL bolesnika bio je 69.5 godina (33-85), umrlih 70 (43-85), a preživjelih 66 godina (33-80). Većina je bolesnika bila muškog spola (26 bolesnika ili 68\%). Od komorbiditeta najčešći su bili arterijska hipertenzija (20-53\%), šećerna bolest (9-24\%) te ishemijska bolest srca (8-21\%). Svi su bolesnici primljeni zbog hipoksemijskog respiratornog zatajenja. Osim respiratornog zatajenja s primjenom mehaničke ventilacije u 30 (79\%) bolesnika, česti su bili šok (2566\%) te akutno bubrežno zatajenje (21- 55\% bolesnika). Metode kontinuiranog nadomještanja bubrežne funkcije primjenjene su kod 13 (34\%) bolesnika. Medijan trajanja hospitalizacije u JIL-u bio je 18 (3-68) dana, a mehaničke ventilacije 17 (5-43) dana. Ukupni je mortalitet bio 50\%, a kod bolesnika koji su zahtijevali mehaničku ventilaciju 63\%. Smrtnost je bila najveća u dobnoj skupini iznad 65. godine.

Zaključak: Bolesnici s COVID-19, liječeni u JL-u, često su i dugotrajno mehanički ventilirani, a tijekom boravka imaju brojne komplikacije bolesti i intenzivnog liječenja te visoku smrtnost. Najveća je smrtnost kod muškaraca stariijh od 65 godina s arterijskom hipertenzijom, šećernom bolesti i ishemijskom bolesti srca.

Abstract

Objective: To describe the characteristics, clinical course, treatment, outcomes and complications in critically ill patients with COVID-19 treated in the intensive care unit (ICU) at the University Hospital for Infectious Diseases „Dr. Fran Mihaljević" (UHID) in Zagreb.

Materials and methods: A retrospective observational study of 38 adult patients with COVID-19 treated in the ICU at UHID between March 11 and June 6, 2020.

Results: Among the 167 patients with COVID-19 treated at the UHID, 38 (22,8\%) were admitted to the ICU. The mean age of these patients was 69.5 (33-85) years, 70 (43-85) years in deceased patients and 66 (33-80) in survivors. The majority of patients were male (26 patients- 68\%). The mMost common comorbidities were arterial hypertension (20-53\%), diabetes mellitus (9-24\%) and ischaemic heart disease (8- 21\%). All patients were admitted for hypoxaemic respiratory failure. In addition to acute respiratory failure with the need for mechanical ventilation (30-79\%), shock (25-66\%) and acute renal insufficiency (21-55\%) were common. Continuous renal replacement therapy was used in 13 (34\%) patients. The median duration of ICU stay was 18 (3-68) days and of mechanical ventilation 19 (5-43) days. Overall mortality was 50\%, 63\% in patients who received mechanical ventilation and it was the highest in patients over 65 years of age.

Conclusions: Patients with COVID-19, treated in the ICU, often require prolonged mechanical ventilation, have numerous complications of critical illness and ICU treatment, and high mortality rates. Mortality rate is highest in men over 65 years with comorbiditeies - arterial hypertension, diabetes mellitus and ischaemic heart disease.
Uvod

Od prvih opisanih slučajeva u prosincu 2019. godine, bolest uzrokovana SARS-CoV-2 virusom (COVID-19) brzo se proširila diljem svijeta, zbog čega je Svjetska zdravstvena organizacija 11. ožujka 2020. godine proglasila pandemiju COVID-19. Dosad je prijavljeno više od 11 milijuna potvrđenih slučajeva COVID-19 i više od 530000 smrtnih slučajeva na glo- 
balnoj razini ${ }^{[1]}$. Bolest se klinički najčešće očituje kao blaga respiratorna bolest, ali je moguć i razvoj teške, pa i kritične bolesti sa zatajenjem disanja, šokom i multiorganskom disfunkcijom kod oko pet posto bolesni$\mathrm{ka}^{[2]}$. Nacionalni krizni stožer i Krizni stožer Ministarstva zdravstva RH je 25. veljače 2020. objavio kako je u Hrvatskoj, u Zagrebu dijagnosticiran prvi slučaj bolesti uzrokovane infekcijom SARS-CoV-2. Do 7. srpnja u Hrvatskoj je potvrđeno 3220 slučajeva sa 113 smrtnih ishoda ${ }^{[3]}$. U Klinici za infektivne bolesti „Dr. Fran Mihaljević" (KZIB) u Zagrebu je do 6. lipnja liječeno ukupno 167 bolesnika s COVID-19. Cilj je ove studije prikazati karakteristike, terapiju, ishod i komplikacije kod kritično oboljelih s COVID-19 liječenih u Jedinici intenzivnog liječenja (JIL) specijaliziranoj za liječenje bolesnika s hipoksemijskim respiratornim zatajenjem.

\section{Materijali i metode}

Riječ je o opservacijskoj retrospektivnoj studiji kritično oboljelih s COVID-19 liječenih u JIL KZIB u Zagrebu. Naša je ustanova specijalizirana za liječenje infektivnih bolesti s 242 kreveta, uz JIL koji, u izvanepidemijskim uvjetima, raspolaže s 18 kreveta te djeluje kao Referentni centar za izvantjelesnu oksigenaciju akutno respiratorno ugroženih bolesnika (vv-ECMO). Podaci su prikupljeni retrospektivno iz medicinske dokumentacije za razdoblje od 11. ožujka 2020. do 6 . lipnja 2020. godine. Uključeni su odrasli bolesnici iznad 18 godina života $s$ infekcijom SARS-CoV-2 virusom dokazanom ili molekularnom in-house qRT-PCR metodom (Corman et al. 2020) ili komercijalnim dijagnostičkim testom Cobas SARS-CoV-2 (Roche Diagnostics) na Cobas 6800 analizatoru $^{[4]}$. Istraživanje je odobrilo Etičko povjerenstvo Klinike za infektivne bolesti „Dr. Fran Mihaljević”. Kritično oboljeli su identificirani kao oni s potrebom za oksigenoterapijom $\mathrm{s}$ udjelom udahnutog kisika iznad 0.6 ili mehaničkom ventilacijom te $s$ prisutnošću poremećaja svijesti ${ }^{[5]} \mathrm{ili}$ hemodinamske nestabilnosti ${ }^{[6]}$. Težina bolesti je proci- jenjena prema APACHE II zbroju ${ }^{[7]}$ i SOFA skoru ${ }^{[8]}$. Dijagnoza akutnog respiratornog distres sindroma (engl. acute respiratory distress syndrome, ARDS) postavljena je prema Berlinskoj definiciji, septičkog šoka prema Sepsis-3 kriterijima, a dijagnoza renalne insuficijencije prema KDIGO (engl. Kidney Disease Improving Global Outcomes) kriterijima ${ }^{[9-11]}$. Dijagnoza pneumonije povezane s mehaničkom ventilacijom (engl. ventilator associated pneumonia, VAP) postavljena je kod bolesnika s novim ili progresivnim radiološkim infiltratom nakon više od 48 sati mehaničke ventilacije s kliničkim znakovima infekcije (novim febrilitetom, purulentnim respiratornim sekretom, leukocitozom, padom u oksigenaciji) s potvrđenim mikrobiološkim izolatom iz ispirka traheje ${ }^{[12]}$. Prikazane su karakteristike bolesnika i njihovi komorbiditeti, tijek bolesti i terapija te ishod i komplikacije. Primarna je mjera ishoda bio mortalitet bolesnika, a sekundarni učestalost i trajanje mehaničke ventilacije te duljina liječenja u JIL-u.

\section{Rezultati}

\section{Karakteristike bolesnika liječenih u JIL-u}

U razdoblju od 11. ožujka do 6. lipnja 2020., u JIL-u KZIB liječeno je ukupno 38 bolesnika s dokazanim COVID-19. Demografske su karakteristike bolesnika navedene u Tablici 1 te na Slici 1. Medijan dobi bolesnika bio je 69.5 godina, $s$ rasponom od 33 do 85 godina, kod umrlih bolesnika medijan je bio 70, a kod preživjelih 66 godina. Značajno je veći broj bolesnika bio muškog spola ( 26 bolesnika, 68\%). Komorbiditeti bolesnika navedeni su u Tablici 2 . Od svih bolesnika, njih sedmero nije imalo drugih bolesti, a jedan je bolovao samo od arterijske hipertenzije. Najčešći su komorbiditeti bili arterijska hipertenzija, šećerna bolest, ishemijska bolest srca te astma/kronična opstruktivna plućna bolest. Medijan Charlson Comorbidity Indeksa (CCI) bio je 3 , s predviđenim 10-godišnjim preživljenjem 53\%.

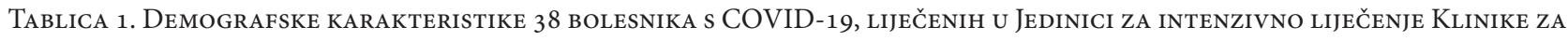
infeKtivne bolesti „Dr. Fran Mihaljević” U Zagrebu

Table 1. Demographic characteristics of 38 patients with COVID-19 treated in the intensive Care unit at the UniverSity Hospital for Infectious Diseases „Dr. Fran Mihaljević” in Zagreb

\begin{tabular}{|l|l|l|l|l|}
\hline & svi (N=38) & preživjeli (N=19) & umrli (N=19) & p vrijednost \\
\hline Dob, medijan (raspon), godine & $69.5(33-85)$ & $66(33-80)$ & $70(43-85)$ & - \\
\hline Spol, muški, broj (\%) & $26(68)$ & $12(63)$ & $14(74)$ & $<.0485$ \\
\hline Spol, ženski, broj (\%) & $12(32)$ & $7(37)$ & $5(26)$ & \\
\hline
\end{tabular}


SLIKA 1. RASPODJELA 38 BOLESNIKA S COVID-19 LIJEČENIH U JEDINICI ZA INTENZIVNO LIJEČENJE KLINIKE ZA INFEKTIVNE BOLESTI „Dr. Fran Mihaljević” u Zagrebu po dobi i spolu

Figure 1. Distribution of 38 Patients with COVID-19 treated in the intensive Care unit at the University Hospital for Infectious Diseases „Dr. Fran Mihaljević” in Zagreb ACCording to Age AND Gender

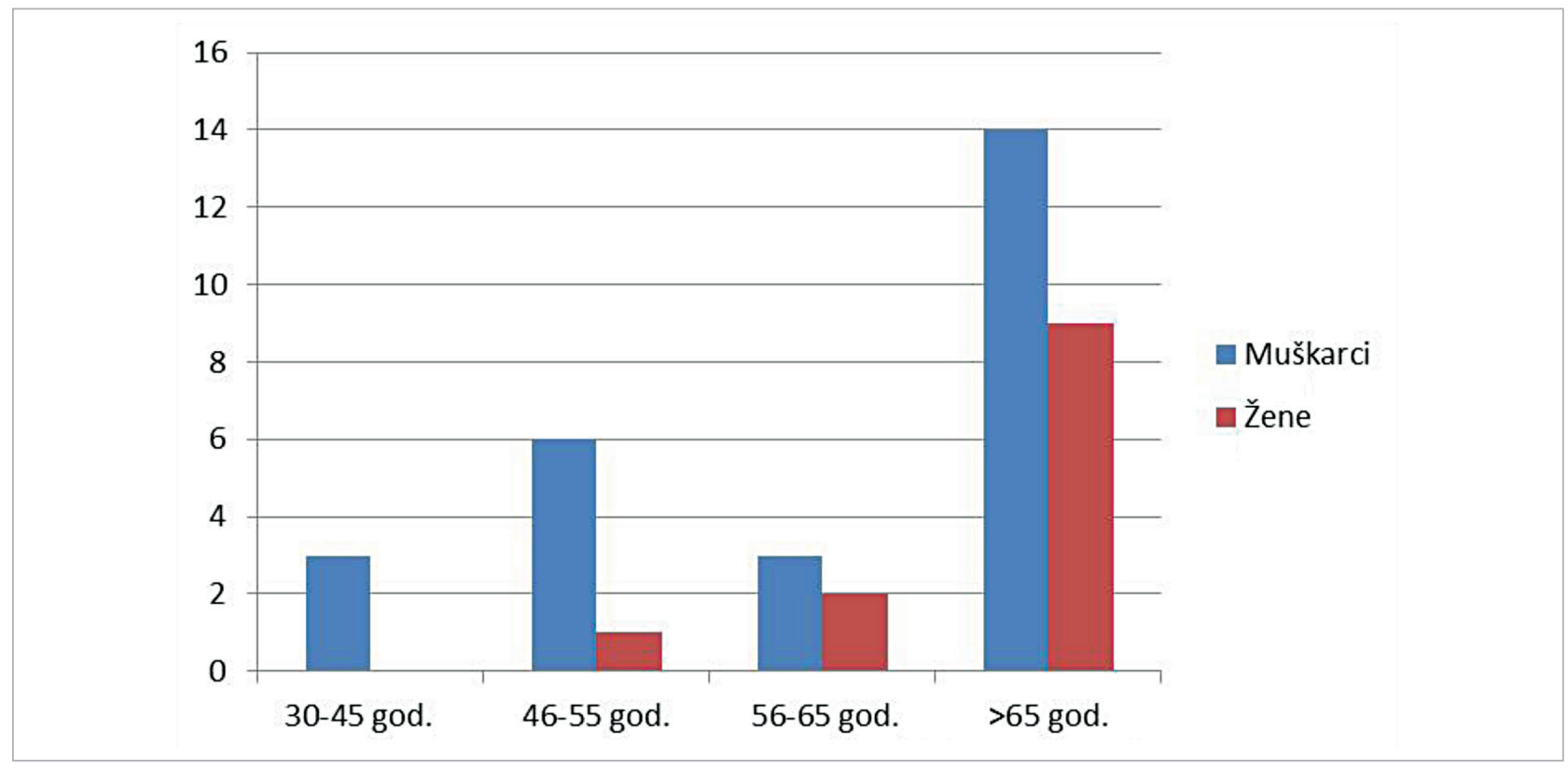

Tablica 2. Komorbiditeti 38 bolesnika s COVID-19 LijeČenih u Jedinici Za Intenzivno lijeČenje KLinike Za infektivne Bolesti „Dr. Fran Mihaljević” u Zagrebu

Table 2. Comorbidities of 38 Patients with COVID-19 treated in the intensive Care unit at the University Hospital for Infectious Diseases „Dr. Fran Mihaljević” in ZaGreb

\begin{tabular}{|c|c|c|c|}
\hline & $\begin{array}{l}\mathrm{Br} . / \% \\
(\mathrm{~N}=38)\end{array}$ & & $\begin{array}{l}\mathrm{Br} / / \% \\
(\mathrm{~N}=38)\end{array}$ \\
\hline Arterijska hipertenzija & $20 / 53$ & Tumori solidnih organa & \\
\hline Šećerna bolest & $9 / 24$ & u anamnezi & $4 / 10$ \\
\hline Ishemijska bolest srca & $8 / 21$ & aktivno liječenje & $2 / 5$ \\
\hline Astma/KOPB & $5 / 13$ & Adipozitet (BMI>30) & $4 / 10$ \\
\hline Neurološki i neurorazvojni poremećaji & & Kronične bolesti bubrega & \\
\hline cerebrovaskularna bolest & $4 / 10$ & transplantirani bubreg & $1 / 2$ \\
\hline epilepsija & $1 / 2$ & Kronične bolesti jetre & \\
\hline multipla skleroza & $1 / 2$ & ciroza jetre & $1 / 2$ \\
\hline kraniocerebralna trauma- tetrapareza & $1 / 2$ & Hematološke bolesti & \\
\hline Psihijatrijske bolesti & & mijelodisplastični sindrom & $1 / 2$ \\
\hline anksioznost/depresija & $4 / 10$ & Imunosupresija & \\
\hline Endokrinološke bolesti & & kemoterapija & $1 / 2$ \\
\hline hiperlipidemija & $4 / 10$ & transplantacija & $1 / 2$ \\
\hline hipotireoza & $2 / 5$ & Pušenje ${ }^{1}$ & 0 \\
\hline
\end{tabular}

${ }^{1}$ za 7 bolesnika nema podataka / no data for 7 patients

\begin{tabular}{|l|l|l|l|}
\hline & $\begin{array}{l}\text { svi } \\
(\mathbf{N}=38)\end{array}$ & $\begin{array}{l}\text { preživjeli } \\
(\mathbf{N}=19)\end{array}$ & $\begin{array}{l}\text { umrli } \\
(\mathbf{N}=19)\end{array}$ \\
\hline Charlson Comorbidity Indeks, medijan (raspon) & $3(0-10)$ & $3(0-7)$ & $3(0-10)$ \\
\hline
\end{tabular}




\section{Tijek bolesti i terapija}

Medijan vremena od početka simptoma do prijema u JIL bio je 10 dana, a od hospitalizacije do prijema u JIL 1.5 dan. Na liječenje smo iz drugih ustanova primili 16 bolesnika $(42,1 \%)$, od kojih je $9(23,7 \%)$ premješteno na mehaničkoj ventilaciji, a kod jednog je bolesnika $(2,6 \%)$, uz mehaničku ventilaciju već prije premještaja, započet vv-ECMO. Svi su bolesnici primljeni zbog hipoksemijskog respiratornog zatajenja. ARDS je razvilo 30 bolesnika (79\%)- 2 blagi (5,3\%), 12 umjereno teški $(31,6 \%)$ te 16 teški ARDS $(42,1 \%)$. Invazivna mehanička ventilacija je primijenjena kod 30 bolesnika (79\%), uz medijan trajanja mehaničke ventilacije od 17 dana. Od navedenih je bolesnika kod troje, uz mehaničku ventilaciju, primijenjena vv-ECMO (10\%). Četvero je bolesnika (13\%) stavljano u položaj na trbuhu radi poboljšanja oksigenacije, 17 (56\%) je primalo neuromuskularni blokator vercuronij kontinuirano ili intermitentno zbog asinkronije, a 20 (66\%) ih je perkutano traheotomirano. Medijan APACHE II zbroja kod na- ših bolesnika bio je 15.5 (za preživjele bolesnike 12, a za umrle 18). Medijan SOFA zbroja svih bolesnika kod prijema je bio 5 (za preživjele 4 , a za umrle bolesnike 6) (Tablica 3). Akutno bubrežno zatajenje razvio je 21 bolesnik (55\%), a kod 13 smo bolesnika (34\%) primijenili metode kontinuiranog nadomještanja bubrežne funkcije. Povišene vrijednosti transaminaza, kao znak jetrene lezije, kod prijema je imalo 33 (87\%) bolesnika. Noradrenalin smo tijekom hospitalizacije primijenili kod 25 (66\%) bolesnika.

Većina je bolesnika primala terapiju (hidroksi) klorokinom (34 tj. 89,5\%), a kombinaciju lopinavira i ritonavira primalo je 7 bolesnika. Kortikosteroidi su primijenjeni kod 21 bolesnika (parenteralni metilprednizolon) $1 \mathrm{mg} / \mathrm{kg}$ tt 5-10 dana, a troje je primilo tocilizumab (još je jedan bolesnik primio tocilizumab $\mathrm{u}$ vanjskoj ustanovi prije premještaja). Azitromicin je primilo 27 bolesnika (71\%), a druge je antibiotike zbog dokazane ili pretpostavljene bakterijske koinfekcije primilo 37 bolesnika $(97,4 \%)$.

TABLICA 3. KLINIČKE OSOBINE I LABORATORIJSKI NALAZI KOD PRIJEMA U 38 BOLESNIKA S COVID-19 LIJEČENIH U JEDINICI ZA INTENZiVno liječEnje Klinike Za infeKtivne bolesti „Dr. Fran Mihaljević” u Zagrebu

TABle 3. Clinical CHARACTERISTICS AND LABORATORY FINDINGS OF 38 PATIENTS WITH COVID-19 TREATED IN THE INTENSIVE CARE unit at the University Hospital for Infectious Diseases „Dr. Fran Mihaljević” in Zagreb

\begin{tabular}{|c|c|}
\hline $\mathrm{T}$ tymp $>38^{\circ} \mathrm{C}$, broj bolesnika (\%) & $10(26)$ \\
\hline Srednji arterijski tlak, medijan (raspon), $\mathrm{mmHg}^{1}$ & $98.5(44-137)$ \\
\hline Resp. frekvencija, medijan (raspon), $/ \mathrm{min}^{2}$ & $27(15-50)$ \\
\hline Frekvencija srca, medijan (raspon), /min & $91(68-140)$ \\
\hline GCS, medijan (raspon) $)^{3}$ & $15(3-15)$ \\
\hline Broj leukocita, medijan (raspon), x109/1 & $10(4.4-27.4)$ \\
\hline Broj limfocita, medijan (raspon), x109/ $1^{4}$ & $0.6(0.1-10.2)$ \\
\hline Broj trombocita, medijan (raspon), $x 10^{9} / 1$ & $209(58-663)$ \\
\hline CRP, medijan (raspon), mg/dL & $158.6(28-371)$ \\
\hline Prokalcitonin, medijan (raspon), $\mu \mathrm{g} / \mathrm{L}$ & $0.929(0.084-59.7)$ \\
\hline INR, medijan (raspon) & $1.12(0.96-4.93)$ \\
\hline Kreatinin kinaza, medijan (raspon), U/L & $176(15-18745)$ \\
\hline Laktat dehidrogenaza, medijan (raspon), U/L & $536(153-2224)$ \\
\hline Troponin, medijan (raspon), $\mu \mathrm{g} / \mathrm{L}^{5}$ & $0.037(0.007-0.273)$ \\
\hline NT-pro-BNP, medijan (raspon), ng/L ${ }^{6}$ & $1640(134-35000)$ \\
\hline AST, medijan (raspon), U/l & $70(17-441)$ \\
\hline ALT, medijan (raspon), U/l & $49(13-352)$ \\
\hline Bilirubin, medijan (raspon), mmol/l & $12(7-193)$ \\
\hline
\end{tabular}




\begin{tabular}{|l|l|}
\hline Kreatinin, medijan (raspon), mmol/l & $89(34-522)$ \\
\hline Laktat, medijan (raspon), mmol/l & $1.45(0.63-7.62)$ \\
\hline Pozitivna hemokultura kod prijema, broj & 0 \\
\hline SOFA zbroj, medijan (raspon) 7 & $5(0-18)$ \\
\hline APACHE II zbroj, medijan (raspon) & $15.5(6-37)$ \\
\hline RTG pluća & \\
\hline obostrani infiltrati, broj bolesnika (\%) & $35(92)$ \\
\hline jednostrani infiltrat, broj bolesnika (\%) & $3(8)$ \\
\hline pleuralni izljev, broj bolesnika (\%) & $13(34)$ \\
\hline pneumotoraks, broj bolesnika (\%) & $1(3)$ \\
\hline
\end{tabular}

${ }^{1} 2$ bolesnika premještena na infuziji vazopresora

${ }^{2} 9$ bolesnika premješteno na MV

${ }^{3} 9$ bolesnika premješteno uz sedaciju

${ }^{4}$ kod 1 bolesnice postavljena sumnja na kroničnu limfocitnu leukemiju tijekom hospitalizacije

${ }^{5}$ rađen kod 23 bolesnika

${ }^{6}$ rađeno kod 21 bolesnika

${ }^{7}$ nije uračunato 6 preživjelih bolesnika- nema ABS kod prijema

\section{Ishod i komplikacije}

Podaci o kliničkom tijeku i ishodu bolesnika navedeni su u Tablici 4. Ukupno je umrlo 19 bolesnika (50\%). Od preminulih 14 su bili muškarci (sa smrtnošću 54\%), a 5 žene (sa smrtnošću 42\%). U dobi iznad 65 . godine života smrtnost je bila 56\%, a kod mlađih 40\%. Kod bolesnika, kod kojih je primijenjena mehanička ventilacija, smrtnost je bila $63 \%$. Sva trojica bolesnika, kod kojih je provođena vv-a ECMO, su umrla. Medijan vremena od prijema u JIL do smrtnog ishoda bio je 16 dana. Medijan trajanja boravka u JIL-u bio je 18 dana, a trajanja mehaničke ventilacije 17 dana.
Glavni je uzrok smrti bio šok. Od komplikacija su najčešće bile šok ( 25 bolesnika tj. 66\%) i akutna renalna insuficijencija (21 bolesnik, 55\%). Nozokomijalna je sepsa etiološki dokazana kod 9 bolesnika (24\%) - od uzročnika su izolirani koagulaza-negativni stafilokok u petero, Acinetobacter baumannii kod troje te K. pneumoniae ESBL kod jednog bolesnika. Pod kliničkom slikom sindroma sepse nedokazane etiologije liječeno je još 18 bolesnika. Ostale su komplikacije navedene u Tablici 5. Jedan je bolesnik premješten u drugu ustanovu radi kirurškog zbrinjavanja pneumotoraksa nastalog kao komplikacija traheotomije.

TABLICA 4. KLINIČKi TIJEK I ISHOD BOLESNIKA S COVID-19 LIJEČENIH U JEDINICI ZA INTENZIVNO LIJEČENJE KLINIKE ZA INFEKTIVNE BOLESTi „Dr. Fran Mihaljević” U Zagrebu

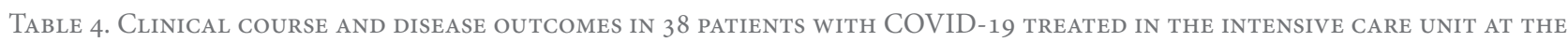
University Hospital for Infectious Diseases „Dr. Fran Mihaljević” in Zagreb

\begin{tabular}{|c|l|}
\hline Vrijeme od pojave simptoma do prijema u JIL, medijan (raspon), dani & $10(1-26)$ \\
\hline Vrijeme od hospitalizacije do prijema u JIL, medijan (raspon), dani & $1.5(0-25)$ \\
\hline Vrijeme boravka u JIL-u, medijan (raspon), dani & $18(3-68)$ \\
\hline svi & $20(3-68)$ \\
\hline preživjeli & $16(5-42)$ \\
\hline umrli & $30(79)$ \\
\hline Invazivna mehanička ventilacija- broj bolesnika (\%)
\end{tabular}




\begin{tabular}{|l|l|}
\hline Trajanje invazivne mehaničke ventilacije, medijan (raspon), dani & \\
\hline svi & $17(5-43)$ \\
\hline preživjeli & $18(13-43)$ \\
\hline umrli & $16(5-42)$ \\
\hline vv ECMO, broj bolesnika (\%) & $3(8)$ \\
\hline Hemodijaliza - broj bolesnika (\%) & $13(34)$ \\
\hline Primjena vazopresora - broj bolesnika (\%) & $25(66)$ \\
\hline Umrli - broj (\%) & $19(50)$ \\
\hline svi & $19(63)$ \\
\hline mehanički ventilirani & $16(5-42)$ \\
\hline Vrijeme od prijema u JIL do smrti, medijan (raspon), dani & \\
\hline
\end{tabular}

SLIKE 2. \& 3. RASPODJELA PO DOBI, SPOLU I SMRTNOSTI KOD BOLESNIKA S COVID-19 LIJEČENIH U JEDINICI ZA INTENZIVNO LIJEČENJE Klinike Za infektivne bolesti „Dr. Fran Mihaljević” U Zagrebu

Figures 2. \& 3. Distribution by age, Sex And mortality in 38 Patients With COVID-19 treated in the Intensive Care Unit at the University Hospital for Infectious Diseases „Dr. Fran Mihaljević” in Zagreb

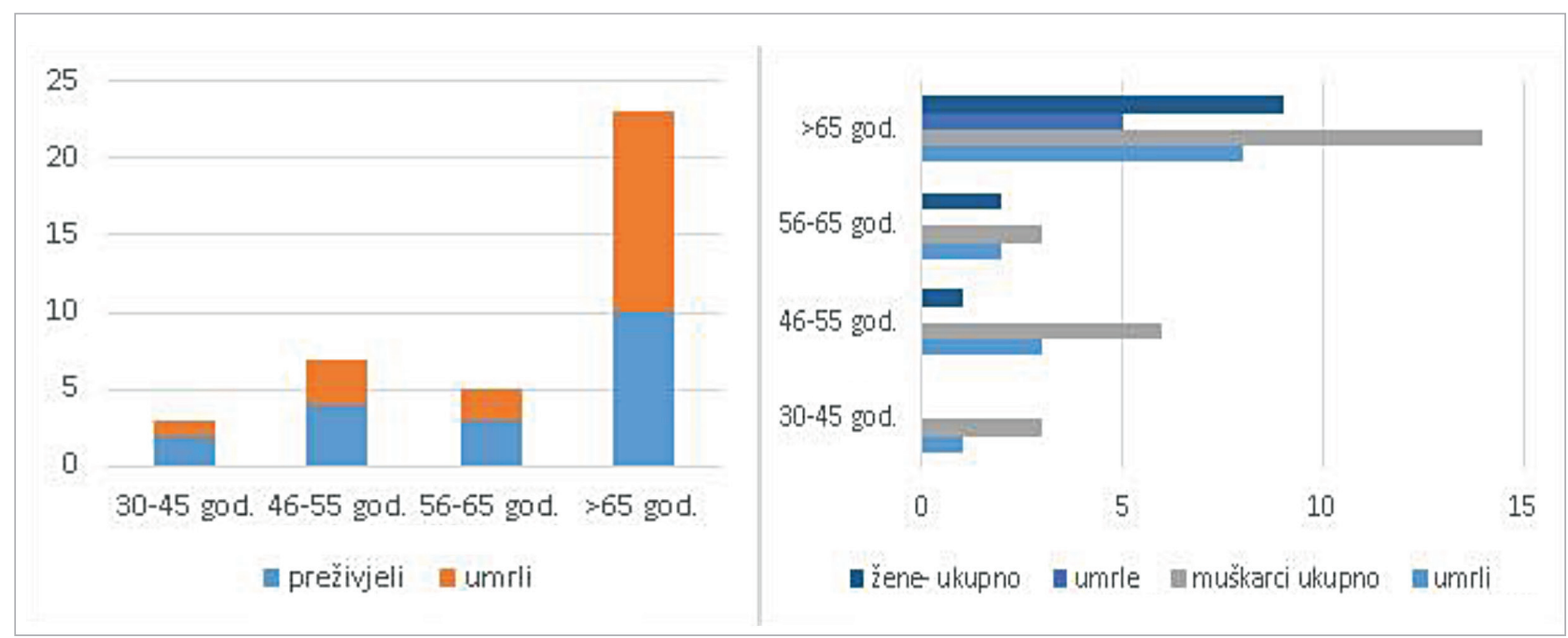

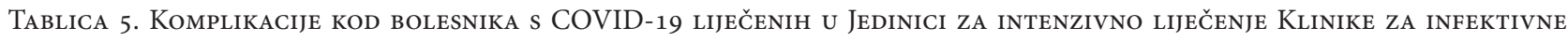
Bolesti „Dr. Fran Mihaljević” U Zagrebu

Table 5. Disease Complications in 38 Patients with COVID-19 treated in the Intensive Care unit at the University Hospital for Infectious Diseases „Dr. Fran Mihaljević” in Zagreb

\begin{tabular}{|l|l|}
\hline & Broj bolesnika/\% \\
\hline Šok & $25 / 66$ \\
\hline Akutna bubrežna insuficijencija & $21 / 55$ \\
\hline Pneumonija vezana uz mehaničku ventilaciju ${ }^{1}$ & $12 / 40$ \\
\hline Urinarna infekcija & $12 / 31$ \\
\hline
\end{tabular}




\begin{tabular}{|l|l|}
\hline Nozokomijalna sepsa- etiološki dokazana & $9 / 24$ \\
\hline C. difficile enterokolitis & $8 / 21$ \\
\hline Srčana dekompenzacija & $6 / 16$ \\
\hline Fibrilacija atrija s brzim odgovorom ventrikla & $6 / 16$ \\
\hline Subkutani emfizem & $4 / 10$ \\
\hline Jatrogeni pneumotoraks & $4 / 10$ \\
\hline Delirij u JIL & $2 / 5$ \\
\hline Traheoezofagealna fistula & $1 / 3$ \\
\hline Duboka venska tromboza ${ }^{2}$ & $1 / 3$ \\
\hline Heparinom inducirana trombocitopenija & $1 / 3$ \\
\hline
\end{tabular}

${ }^{1}$ u bolesnika na mehaničkoj ventilaciji $(\mathrm{N}=30)$

${ }^{2}$ v. subklavija - bolesnik s centralnim venskim kateterom

\section{Rasprava}

Ovom se studijom opisuje 38 kritično oboljelih bolesnika s laboratorijski potvrđenom COVID-19 i hipoksemijskim respiratornim zatajenjem. Najveći je broj bolesnika koji su zahtijevali intenzivno liječenje bio u dobnoj skupini iznad 65-te. godine života, muškog spola te s više komorbiditeta, najčešće arterijskom hipertenzijom, šećernom bolesti i ishemijskom bolesti srca, što odgovara i dosadašnjim izvještajima ${ }^{[13-17]}$.

Bakterijsku koinfekciju kod prijema u bolnicu nismo dokazali ni kod jednog bolesnika, iako su kod velikog dijela bolesnika zabilježene značajno povišene vrijednosti CRP-a i prokalcitonina. Po tome se COVID-19 bitno razlikuje od influence koja je često povezana s bakterijskom koinfekcijom patogenima koji koloniziraju nazofarinks ${ }^{[18]}$.

Invazivna mehanička ventilacija je, zbog razvoja ARDS-a, primjenjena kod 79\% bolesnika s medijanom trajanja mehaničke ventilacije od 17 dana, što ukazuje na činjenicu da kod akutne respiratorne insuficijencije u sklopu COVID-19 može biti potrebna prolongirana mehanička ventilacija koja može trajati i tjednima. Nismo se odlučili na primjenu terapije visokim protokom kisika putem nazalnih kanila i neinvazivne mehaničke ventilacije, s obzirom na mogućnost stvaranja aerosola i rizik prijenosa infekcije na medicinsko osoblje.

Svo troje bolesnika kod kojih je, uz mehaničku ventilaciju, bio potreban vv-ECMO su umrla. S obzirom na mali broj bolesnika koji su zahtjevali vv-ECMO, ne možemo puno zaključiti o ovoj metodi kod COVID-19 bolesnika. Međutim, dojam je da vv-ECMO u ARDS-u tijekom COVID-19 nije toliko efikasan kao kod ostalih infekcija koje mogu uzrokovati ARDS, vjerojat- no zbog nedostatka etiološkog liječenja. Osim toga, kod većine bolesnika s COVID-19 je, i kod teškog ARDS-a, održana popustljivost pluća, što nam omogućava da, uz optimizaciju postavki mehaničke ventilacije, adekvatno oksigeniramo i ventiliramo bolesnike. U slučajevima kada dolazi do takvog urušaja plućne funkcije da je potreban vv-ECMO, oštećenje je pluća jednostavno preveliko, a bolesnik je obično već dulje vrijeme mehanički ventiliran. Iz ranijih je spoznaja već poznato kako te varijable negativno utječu na ishod bolesnika na vv-ECMO potpori zbog ARDS-a ${ }^{[19]}$

U usporedbi s izvješćima iz Kine ${ }^{[20]}$, veći je broj bolesnika razvio akutnu renalnu insuficijenciju te je primijenjena CRRT. Patogeneza renalne insuficijencije u COVID-19 još nije u potpunosti razjašnjena, a mogla bi biti povezana s ACE2, staničnim receptorom za SARS CoV-2, izraženom na respiratornom epitelu, ali i bubrezima ${ }^{[20]}$. Čest je tijekom hospitalizacije bio razvoj distributivnog šoka s potrebom za vazopresorima, u sličnom postotku kao kod izvještaja iz SAD-a ${ }^{[21]}$. Sepsa je etiološki potvrđena izolatom iz hemokultura kod malog broja bolesnika, što ukazuje na to da je šok vjerojatno direktno povezan sa SARS CoV-2 virusom i SIRS odnosno mogućim sindromom prekomjernog lučenja citokina. Gotovo su svi naši bolesnici ipak primali empirijsku antibiotsku terapiju kod prijema, kao i kod nastanka šoka te je u budućnosti potrebno razmisliti o racionalnijoj primjeni antibiotika kod ove skupine bolesnika. Tocilizumab smo primjenili kod tri bolesnika (jedan je primio lijek u vanjskoj ustanovi). Dva su bolesnika imala kliničko poboljšanje, a kod jednog nije polučen učinak. O učinkovitosti tocilizumaba u ovoj indikaciji trebamo pričekati završetak COVACTA 
istraživanja ${ }^{[22]}$, iako jedno istraživanje ${ }^{[23]}$, premda retrospektivno, ukazuje na dobrobit liječenja ovim lijekovima. Većina je naših bolesnika primala „suosjećajnu" antivirusnu terapiju (engl. compassionate use), a s obzirom na maleni uzorak, nemoguće je donijeti bilo kakav zaključak o njezinoj učinkovitosti ili štetnosti. Metilprednizolon smo primijenili kod 21 bolesnika, vođeni dosadašnjim zaključcima da bi kortikosteroidi mogli biti povezani s boljim kliničkim ishodom kod bolesnika s COVID-19 i ARDS-om ${ }^{[24-25]}$, no oko njihove su primjene potrebna daljnja istraživanja.

Ukupna je smrtnost naših bolesnika bila 50\%, što je slično izvještajima kod kritično oboljelih iz Kine ${ }^{[26]}$ te nekim izvještajima iz SAD-a ${ }^{[21]}$. Slično navedenim izvještajima, najveća je smrtnost zabilježena u dobnoj skupini iznad 65 . godine života, te kod bolesnika muškog spola s komorbiditetima.

Ova studija ima svoja ograničenja. Obuhvaća mali broj bolesnika, a neke od pretraga nisu učinjene kod svih bolesnika, prije svega acidobazni status kod šest od osam bolesnika koji nisu mehanički ventilirani, što utječe na vrijednosti APACHE II i SOFA skora kod preživjelih bolesnika, koji bi vjerojatno bili i niži.

Najveća je vrijednost ovog istraživanja prikaz ishoda liječenja u Jedinici intenzivnog liječenja ustanove tercijarne zdravstvene zaštite gdje se liječe najteži bolesnici oboljeli od nove, teške, virusne pandemijske bolesti.

Zaključno, prema našem dosadašnjem iskustvu, bolesnici s COVID-19 koji se primaju u JIL često se i dugotrajno mehanički ventiliraju, a tijekom boravka imaju brojne komplikacije bolesti i intenzivnog liječenja uz visoku smrtnost. Nepovoljni je ishod najčešći kod muškaraca starijih od 65 godina $s$ arterijskom hipertenzijom, šećernom bolesti i ishemijskom bolesti srca.

\section{LITERATURA}

${ }^{[1]}$ WHO. Coronavirus disease (COVID-19) Weekly Epidemiological Update and Weekly Operational Update. [Internet]. Geneva: WHO; 2020 [cited 2020 July 7]. Available from: https://www.who.int/emergencies/diseases/novel-coronavirus-2019/situation-reports

${ }^{[2]} \mathrm{Wu} \mathrm{Z}, \mathrm{McGoogan}$ JM. Characteristics of and Important Lessons From the Coronavirus Disease 2019 (COVID-19) Outbreak in China: Summary of a Report of 72314 Cases From the Chinese Center for Disease Control and Prevention. JAMA 2020;323(13):1239-42.

${ }^{[3]}$ HZJZ. Koronavirus - najnoviji podatci. Zagreb: HZJZ; 2020 [cited 2020 July 7]. Available from: https://www.hzjz.hr/priopcenja-mediji/koronavirus-najnoviji-podatci/-

${ }^{[4]}$ Corman VM, Landt O, Kaiser M, et al. Detection of 2019 novel coronavirus (2019-nCoV) by real-time RT-PCR. Euro Surveill 2020;25(3):2000045.
${ }^{[5]}$ Plum F, Posner JB. The diagnosis of stupor and coma. 4th ed. Philadelphia: F.A. Davis; 1995.

${ }^{[6]}$ Vincent JL, De Backer D. Circulatory shock. N Engl J Med 2013;369(18):1726-34.

${ }^{[7]}$ Knaus WA, Draper EA, Wagner DP, Zimmerman JE. APACHE II: a severity of disease classification system. Crit Care Med 1985;13(10):818-29.

${ }^{[8]}$ Vincent JL, Moreno R, Takala J, et al. The SOFA (Sepsis-related Organ Failure Assessment) score to describe organ dysfunction/failure. On behalf of the Working Group on Sepsis-Related Problems of the European Society of Intensive Care Medicine. Intensive Care Med 1996;22(7):707-710.

${ }^{[9]}$ Force ADT, Ranieri VM, Rubenfeld GD, et al. Acute respiratory distress syndrome: the Berlin definition. JAMA 2012; 307(23):2526-33.

${ }^{[10]}$ Singer M, Deutschman CS, Seymour CW, et al. The Third International Consensus Definitions for Sepsis and Septic Shock (Sepsis-3). JAMA 2016;315(8):801-10.

${ }^{[11]}$ Khwaja A. KDIGO clinical practice guidelines for acute kidney injury. Nephron Clin Pract 2012;120(4):c179-84.

${ }^{[12]}$ Fabregas NS, Ewig A, Torres M, et al. Clinical diagnosis of ventilator associated pneumonia revisited: comparative validation using immediate post-mortem lung biopsies. Thorax 1999; 54:867-73.

${ }^{[13]}$ Wu Z, McGoogan JM. Characteristics of and Important Lessons From the Coronavirus Disease 2019 (COVID-19) Outbreak in China: Summary of a Report of 72314 Cases From the Chinese Center for Disease Control and Prevention. JAMA 2020;323(13):1239-42.

${ }^{[14]}$ Petrilli CM, Jones SA, Yang J, et al. Factors associated with hospital admission and critical illness among 5279 people with coronavirus disease 2019 in New York City: prospective cohort study. BMJ 2020;369:m1966.

${ }^{[15]}$ Zhou F, Yu T, Du R, et al. Clinical course and risk factors for mortality of adult inpatients with COVID-19 in Wuhan, China: a retrospective cohort study. Corrected and republished from: Lancet 2020;395(10229):1038] Lancet 2020; 395(10229):1054-62.

${ }^{[16]}$ Richardson S, Hirsch JS, Narasimhan M, et al. Presenting Characteristics, Comorbidities, and Outcomes Among 5700 Patients Hospitalized With COVID-19 in the New York City Area. JAMA 2020;323(20):2052-59.

${ }^{[17]}$ Chen T, Wu D, Chen $\mathrm{H}$, et al. Clinical characteristics of 113 deceased patients with coronavirus disease 2019: retrospective study [Corrected and republished from: BMJ 2020;368:m1295] BMJ 2020;368:m1091.

${ }^{[18]}$ Chertow DS, Memoli MJ. Bacterial coinfection in influenza: a grand rounds review. JAMA 2013;309:275-82.

${ }^{[19]}$ Peek GJ, Clemens F, Elbourne D, et al. CESAR: conventional ventilatory support vs extracorporeal membrane oxygenation for severe adult respiratory failure. BMC Health Serv Res 2006;6:163.

${ }^{[20]} \mathrm{Yu} \mathrm{Y}, \mathrm{Xu} \mathrm{D}, \mathrm{Fu}$ S, et al. Patients with COVID-19 in 19 ICUs in Wuhan, China: a cross-sectional study. Crit Care 2020; 24(1): 219.

${ }^{[21]}$ Bhatraju PK, Ghassemieh BJ, Nichols M, et al. Covid-19 in Critically Ill Patients in the Seattle Region-Case Series. N Engl J Med 2020;382:2012-22.

${ }^{[22]}$ Biran N, Ip A, Ahn J, et al. Tocilizumab among patients with COVID-19 in the intensive care unit: a multicentre observational study. Lancet Rheumatol 2020;2:e603-12. 
${ }^{[23]}$ Clinical Trials.gov. [Internet]. A Study to Evaluate the Safety and Efficacy of Tocilizumab in Patients With Severe COVID-19 Pneumonia (COVACTA). Bethesda (MD): U.S. National Library of Medicine; 2020 [cited 2020 July 7]. Available from: https://clinicaltrials.gov/ct2/show/NCT04320615

${ }^{[24]}$ Wu C, Chen X, Cai Y, et al. Risk Factors Associated With Acute Respiratory Distress Syndrome and Death in Patients With Coronavirus Disease 2019 Pneumonia in Wuhan, China. JAMA Intern Med 2020;e200994.
${ }^{[25]}$ Alhazzani W, Møller MH, Arabi YM, et al. Surviving Sepsis Campaign: guidelines on the management of critically ill adults with Coronavirus Disease 2019 (COVID-19). Intensive Care Med 2020;46:854-87.

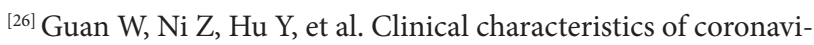
rus disease 2019 in China. N Engl J Med 2020;382:1708-20. 